Review Article

\title{
Water Scarcity in India: A Threat to Sustainable Management of Water
}

Rana, Mamta ${ }^{1}$ and Guleria, Vishal ${ }^{2}$

${ }^{1}$ School of Law, University of Petroleum \& Energy Studies, Dehradun

${ }^{2}$ Department of Law, HNB Garhwal (Central) University, Uttarakhand

Corresponding Author: dr.vishalguleria@gmail.com

\section{A R T I C L E I N F O}

Received: 30 June 2018 | Accepted: 12 September 2018 | Published Online: 31 December 2018

DOI: $10.31786 / 09756272.18 .9 .2 .206$

EOI: $10.11208 /$ essence.18.9.2.206

Article is an Open Access Publication.

This work is licensed under Attribution-Non Commercial 4.0 International

(https://creativecommons.org/licenses/by/4.0/)

CThe Authors (2018). Publishing Rights @ MANU_ICMANU \& ESSENCE-IJERC.

\section{A B S T R A C T}

Water is life for all the living organisms which is present on earth. Water is needed to ensure food security, feed livestock, and take up industrial production and to conserve the environment. Water scarcity involves water stress, water shortage or deficits, and water crisis. This may be due to both nature and humans. Main factors that contribute to this issue include poor management of resources, lack of government attention, awareness and anthropogenic waste. The increased value of solid wastes and other hazardous waste in water systems such as rivers, ponds, lakes and canals also heavily pollute the water quality. Government has to take stringent steps for the protection of natural resources because human being is dependent on environment for every basic needs and life is beyond imagination without natural resource like water.

\section{K E Y W O R D S}

Social skills | Extra-curricular activities | Student | Development

\section{I T A T I O N}

Rana, Mamta and Guleria, Vishal (2018): Water Scarcity in India: A Threat to Sustainable Management of Water. ESSENCE Int. J. Env. Rehab. Conserv. IX (1): 35-44. 


\section{Introduction}

India has a rich heritage, which shows deep reverence towards the environment. Ancient Indians worshipped the forces of nature, including animals and plants. A peep into environmental jurisprudence will show that preservation of environment emanated from spiritual teachings and sacred texts. Gautama Buddha, Mahavira and Prophet Mohammed, had all echoed the same thought of love and harmony between man and environment. India today is confronted by a host of problems and challenges such as growth of population, scarcity of drinking water, deceptive monsoon rains, decline in forests and wild life, soil erosion, lowering of sea level, health hazards due to rise in human diseases, climate change etc. Environmental pollution and the resulting imbalance in eco-systems is the root cause behind these adversities, which need to be addressed on priority basis. It has been universally recognized that human happiness and growth, which are fundamental for the well-being of the society cannot be achieved without protection and conservation of environment. The right to a healthy environment is therefore, recognized as a fundamental human right. The core issue involved in protection of environment is need for maintenance of a proper balance of the eco-system through sustainable development so that natural resources be preserved for future generation without any environmental degradation. These efforts can succeed where there are effective laws for the protection and preservation of environment in its varied forms by adopting an integrated management strategy of sustainable development computable with ecological stability.

\section{International Concern for the Protection of Environment}

The protection of environment is a human right issue so the Universal Declaration of Human Rights (UDHR) protected it in 1948. The growth of technology and industrialization and throughout the world has seen free trade being promoted which is the direct outcome of globalization and the same is resulting in environmental hazards. Since the very inception of protection of environment as human right, protection of environment has become a cause of concern to provide the justice to the affected parties and to take into account the concerns of future generations. The protection and improvement of the human environment is a major issue, which affects the well-being of people and economic development throughout the world. To defend and improve the human environment for the present and future generations has become an imperative goal for humankind-a goal to be pursued together with, and in harmony with the established and fundamental goals of peace and of worldwide economic and social development. Both human population and water resources are distributed unevenly across the globe. In many areas, densely populated regions do not overlap with those that are water rich. Due to the rapidly increasing population and water use per capita in many areas of the world, around one third of the world's population currently lives under physical water scarcity.

When the World Commission on Environment and Development (Brundtland Commission) published its report in 1987, it presented a new concept - sustainable development. The concept became one of the most successful approaches to be introduced in many years. In fact, it helped to shape the international agenda and the international community's attitude towards economic, social and environmental development. The Brundtland Commission's report defined sustainable development as "development which meets the needs of current generations without compromising the ability of future generations to meet their own needs". During the last few decades, it has become evident that because of a steadily increasing demand, freshwater scarcity is 
becoming a threat to sustainable development of human society. In its most recent annual risk report, the World Economic Forum lists water crises as the largest global risk in terms of potential impact.

\section{Sustainable Development}

Nature provides human societies and economies with a complex life support system, air, water, food, and a suitable climate for survival. It also provides the physical resources that are necessary for the sustenance of economies. Nature has supported and maintained life on earth since times immemorial and should continue to do so in the future. This is known as the sustainability of nature or ecosystems or environment.

The term 'sustainability' has been derived variously, such as; sustainability refers to a process or state that can be maintained indefinitely, natural resources must be used in such a way that they do not create ecological debts by over exploiting the carrying and productive capacity of the earth, a minimum necessary condition for sustainability is the maintenance of the total natural capital stock at or above the current level.

The term 'development' means the social and economic improvement in a broad sense. It is needed to create opportunities, prosperity and choices for all inhabitants of the world and it must proceed in a way that leaves choices available for future generations also. It refers to a holistic growth of the human and natural environment towards autonomy and freedom. It indicates a growth pattern, which makes nations more decisive in their internal and external environment. The concept of sustainable development was envisaged to bring environmentalist ideas into the central theme of economic developmental policy. It sought to modify the kind of unsuitable development strategies that were being pursued. Sustainable development combines the two term 'sustainability' and 'development' to indicate a pattern of growth which strengthens both the national capabilities to care for their people in relation to their total relationship with the resources of the earth. The Brundtland Commission in its report 'Our Common Future' (1987) gave the most widely used definition of sustainable development. It defined sustainable development as development, which meets the needs of the present without compromising the ability of future generations to meet their own needs. Since then, several interpretations of sustainable development have emerged, for e.g., (i) Improving the quality of human life while living within the carrying capacity of supporting ecosystems. (ii) Economic growth that provides fairness and opportunity for all the people, not just the privileged few, without further destroying the world's finite natural resources and carrying capacity. (iii) Sustainable development comprises of economic and social development that protects and enhances the natural environment and social equity.

We must also recognize the right of future generations to inherit, as we have, a planet thriving with life, and that continues to afford opportunities to reap economic, cultural and spiritual benefits of nature. Thus, an improvement in human well-being that allows us to meet the needs of the present without compromising the ability of future generation to meet their own needs is called sustainable development in the context of environmental matter.

Sustainable development consists of three important but overlapping steps: save it, know it, and use it. These three components have penetrated the current concept of biodiversity conservation, so much so that conservation is now inseparably intertwined with sustainable development. The right to development is a fundamental human right, as other human rights would be unattainable without the comprehensive development of states, society and individuals. 
The right to development "is an inalienable human right by virtue of which every human person are entitled to participate in, contribute to, and enjoy economic, social, cultural and political development, in which all human rights and fundamental freedoms can be fully realized. In an era of globalization, good global governance is essential for the formulation and implementation of national and international development policies in a manner that respects, promotes and protects all human rights and is aimed at the constant improvement of human wellbeing. The right to development and the right to the environment are both third generation rights, closely related to human development and world peace. The right to the environment is a qualification or capability of humans as individuals and states and nations as collectives of humans to freely enjoy and protect the resources and environment of the earth and promote the harmony between man and nature as well as the sustainable development of society, and is an internal demand of all mankind to live a healthy and fruitful life. For developing countries, there is a de facto conflict between the right to development and the right to the environment, which leads to serious consequences. To coordinate development and the environment, developing countries should shift their pattern of development, take the path of sustainable development and realize environmental protection and ecological balance while promoting economic growth.

The United Nations (UN) and the international community are working on a new development framework to replace the Millennium Development Goals (MDGs) after 2015. This is expected to place environmental sustainability at its core by integrating the Sustainable Development Goals (SDGs) agreed at the Rio+20 UN Conference on Sustainable Development. The importance of environmental sustainability to development was captured in MDG. Despite some progress towards meeting this goal, there is still substantial unfinished business and new global and local challenges endanger the development and environmental gains achieved so far. - The post-2015 framework will need to reflect the linkages between poverty reduction, natural resource management and development, as well as local and global environmental challenges. A key element will be to identify and address a common agenda to collectively manage shared global environmental risks and to build resilience across all types of countries to contribute to inclusive and sustainable development, taking into account complex issues such as the interactions between food, water and energy security. The (SDGs), otherwise known as the Global Goals, are a universal call to action to end poverty, protect the planet and ensure that all people enjoy peace and prosperity. The SDGs came into effect in January 2016, and they will continue to guide United Nations Development Program (UNDP) policy and funding until 2030. As the lead United Nations development agency, UNDP is uniquely placed to help implement the Goals through our work in some 170 countries and territories. The plan focuses on key areas including poverty alleviation, democratic governance and peacebuilding, climate change and disaster risk, and economic inequality. UNDP provides support to governments to integrate the SDGs into their national development plans and policies.

\section{National Concern for the Protection of Environment}

The Indian legal system provides four major sources of law for addressing problems related to water pollution: (1) comprehensive legislation which regulates prevention, preservation and abate of water pollution i.e., Water (Prevention and Control of Pollution) Act, 1974; (2) Environment Protection Act, 1986 also covers water related issues; (3) public nuisance action against polluters; (4) public interest litigations under the aegis of Article 32 and 226 of the Indian Constitution. 
The environment has been defined as that outer physical and biological system in which man and other organisms live as a whole. This entire system is a complicated one as it has many interacting components. These components of the environment generally include its rocks, minerals, soils and waters, its lands and potential vegetation, its animal life and potential for animal husbandry and its climate. There is a close and complicated interaction amongst these various components, which tend to produce a kind of equilibrium in the scheme of nature, which is generally termed as 'ecological balance'.

Section 2(a) of the Environment (Protection) Act, 1986, defines the term "environment". It includes water, air and land and includes the human beings, other living creatures, plants, microorganisms and property.

Right to live in a pollution free environment is the fundamental right of every citizens of India. It has not been mentioned as one of the Fundamental Right under part III but has been explained under the preview of Article 21 of the Indian Constitution. Water is a basic need for the survival of human beings and is part of the right to life and human rights as enshrined in Article 21 of the Constitution.

In Francis Coralie Mullin the Supreme Court declared, "the right to life includes the right to live with human dignity and all that goes with it, namely, the bare necessaries of life such as adequate nutrition, clothing and shelter and facilities for reading, writing and expressing oneself in diverse forms, freely moving about and mixing and commingling with fellow human beings. The magnitude and components of this right would depend upon the extent of economic development of the country, but it must, in any view of the matter, include the bare necessities of life and also the right to carry on such functions and activities as constitute the bare minimum expression of the human self." By stressing on the bare necessities of life, the Court actually made a point on the availability of food, water, shelter, clothing etc. without which human dignity cannot be ensured. The Court recognized that water is a community source, which is to be held by the State in public trust in recognition of its duty to respect the principle of intergenerational equity.

The Resolution of United Nations Organizations (UNO) in 1977 to which India is a signatory, during the United Nations Water Conference resolved unanimously, inter-alia, as under:

"All the people, whatever their stage of development and their social and economic conditions, have the right to have access to drinking water in quantum and of quality equal to their basic needs."

The United nations also emphasized on the importance of drinking water in a proclamation on 10th November ,1980 "International Drinking Water Supply and Sanitation Decade".

In State of Orissa v. Government of India, Katju, J., opined that the right to get water is a part of life guaranteed by Article 21 of the Constitution. It is a gift of nature. Human hand cannot be permitted to convert this bounty into a curse, an oppression. Right to life guaranteed in any civilized society, inter alia, right to water and descent environment. These are basic human rights known to any civilized society.

Article 39 (b) provides: "The State shall, in particular, direct its policy towards securing . . . that the ownership and control of the material resources of the community are so distributed as best to sub serve the common good." Supreme Court in M.C. Mehta v. Kamal Nath emphasized that Indian legal system is essentially based on English common law, and includes the public trust doctrine as part of its jurisprudence. The state is the trustee of all natural resources, which are by nature meant for public use and enjoyment. Public at large is the beneficiary of seashore, running waters, airs, forests, and ecologically fragile 
lands. The state as trustee is under a legal duty to protect the natural resources. These resources meant for public use cannot be converted into private ownership.

In Vellore Citizens Welfare Forum v. Union of India, the apex court adopted the principle to check pollution of underground water caused by the leather industries in Tamil Nadu. Supreme Court in this case laid down that the two principles of sustainable development (polluter pays principle and precautionary principle) are the part of environmental law of the country and can be derived from various provisions including the right to life under Article 21 of the Constitution.

In M.C. Mehta v. Union of India, which concerned the pollution of the river Ganga, the Supreme Court reaffirmed the duty of the government, under Article 21, to ensure a better quality of environment and ordered the government to improve its sewage system.

In A.P. Pollution Control Board v. Prof. M.V. Nayadu, the Court held that the right to access to drinking water is fundamental to life and that the state has a duty under Article 21 to provide clean drinking water to its citizens .

In Narmada Bachao Andolan v. Union of India, the Supreme Court has derived the right to water as a human right from the right to life. Here the Court says, water is the basic need for the survival of the human beings and is part of right of life and human rights as enshrined in Article 21 of the Constitution of India." Now it is, therefore, clear that the Supreme Court beyond any doubt recognizes the right to water as a human right and a fundamental right .In M. C. Mehta v. Union of India, the Supreme Court of India recognized that groundwater is a public asset, and that citizens have the right to the use of air, water, and earth as protected under Article 21 of the Constitution.

\section{Water Crisis in India}

A Threat to Sustainable Management: Water is one of the most important commodities which man has exploited than any other resource for sustenance of his life. Most of the water on this planet is stored in oceans and ice caps which is difficult to be recovered for our diverse needs. Most of the demand of water is fulfilled by rainwater which gets deposited in surface and ground water resources. The quantity of this utilizable water is very limited on earth. Most of the surface waters in India, including both rivers and lakes are getting increasingly polluted due to onslaught of human activities of diverse nature. Though several steps have been taken on a broader front including National River and lakes conservation plans but the quality of water resources seems to be far from satisfactory. This is mainly due to lack of coordination between various governing bodies and proper operation and maintenance of treatment plants and various other reasons like reluctance of people and frequent failures of electricity due to which untreated sewage or industrial wastes are directly discharged into water bodies. The river Ganga which is considered most important river is practically a toxic dump of highly polluting industries and municipal corporations. This has further led to scarcity of water as these major sources of clean water are now getting unusable, be it rivers or be it other water bodies.

In the recent past, there have been instances which have captured the fancy of the nation for the imminent threat of water scarcity. The most recent was the glaring water shortage faced by Shimla city which was aptly highlighted by the print and electronic media. Shimla and Bengaluru are two very disparate cities. One is a quaint hill station that acts as a summer retreat for most Indians while the other is a bustling IT hub, which makes it a popular destination for most of the corporates in India. Both are poles apart and, quite aptly, situated in opposite ends of the country. The only sliver of commonality between the two cities is the unfortunate water crisis that is currently afflicting daily life in both regions. Shimla ran out 
of water towards the end of May this year while earlier Bengaluru was listed as one the cities in the world that were most likely to suffer a similar fate.

To Zeno the whole universe consisted of one substance, and this substance was reason. The law of nature was to him identical with the law of reason. Man, a part of cosmic nature, was an essentially rational creature. In following the dictates of reason, he was conducting his life accordance with the laws of his own nature. As per the ideology, human beings have to discern what is reasonable for them. The way we are growing with the technology, globalization and urbanization, the unplanned growth and is the root cause of environmental destruction. As per 42nd amendment in the Indian Constitution Article 51 A (g) confers duty on the citizens to protect and conserve natural resources. Some of the reasons for the cause of water pollution are poor sewage system, disposal of effluents, industrial waste, municipal waste and garbage into river. Climate change, scanty rainfall, population growth, heavy abstraction of water for irrigation, improper agricultural activities leads to water pollution and water crisis in India. Global warming would affect the rainfall and it leads to drought and water crisis. Latur is one of the districts in Maharashtra in Marathwara region witnessed severe water crisis because of draught and it had taken the lives of the farmers. In the same region, Municipal Corporation decided to give water supply once in a month. Unplanned construction and development has affected the water table.

"Water is essential for life. The amount of fresh water on earth is limited, and its quality is under constant pressure. Preserving the quality of fresh water is important for the drinking-water supply, food production and recreational water use. Water quality can be compromised by the presence of infectious agents, toxic chemicals, and radiological hazards. "World Health Organization" (WHO)
It is sad that India is undergoing the worst water crisis in its history. Already, more than 600 million people are facing acute water shortages. NITI Aayog has recently launched an Index of Health that seeks to capture the annual progress of States/ UTs on a variety of health indicators. As a major leap in this direction, NITI Aayog has come out with a Composite Water Management Index as a useful tool to assess and improve the performance in efficient management of water resources. It's a matter of concern that 600 million people in India face high to extreme water stress in the country. About three-fourth of the households in the country do not have drinking water at their premise. With nearly $70 \%$ of water being contaminated, India is placed at 120th amongst 122 countries in the water quality index. It is a fact that water is a State subject and its optimal utilization and management lies predominantly within the domain of the States. This index is an attempt to budge States and UTs towards efficient and optimal utilization of water and recycling thereof with a sense of urgency.

It is said that if nothing changes, things would get much worse. The best estimates indicate that India's water demand will exceed supply by a factor of two by 2030, with severe water scarcity on the horizon for hundreds of millions. "By 2030, the country's water demand is projected to be twice the available supply, implying severe water scarcity for hundreds of millions of people and an eventual $\sim 6 \%$ loss in the country's GDP". The report added that the total availability of water is still "lower than this projected demand, at 1,137 BCM". "Thus, there is an imminent need to deepen our understanding of our water resources and usage and put in place interventions that make our water use efficient and sustainable". 21 Indian cities-including Delhi, Bengaluru, Chennai and Hyderabad-will run out of groundwater by 2020 , affecting 100 million people; $40 \%$ of India's population will have no access to drinking water by 2030 , the report said. Currently, many Indian 
states, including Andhra Pradesh, Chhattisgarh and Tamil Nadu, face water shortages, exacerbated by changing pattern of rainfall. Somehow, the report released by the Niti Ayog is a question mark on the SDGs (one of them is focused on the clean water) which UNDP released and looking forward to meet by 2030 . This is an alarming situation. Life on earth without air and water cannot be imagined.

\section{Conclusion and Suggestions}

Social solidarity which the human beings share with the environment led to the growth of various initiatives in the past and present to safeguard and preserve the environment. The problem of environmental pollution is not new and not related to the nature of modern technology. The problem was recognized in the past as well but presently the scientific and technological developments added more fuel to the fire. The initiatives were taken in the past to protect environment and can be traceable from Vedas where the significance of the nature is manifested in the form of Prithvi, Agni, Jal, Akash and Vayu. Manu highlighted not to contaminate water by passing urine, stool and poison in it. Yajnavalkya smriti also highlighted the importance and purity of water. The importance of environment was also acknowledged in Kautilyas Arthasashtra and it also prescribed punishments for cutting tree and forest. The importance of environment was also accredited by holy Koran, which declares, "We made from water every living things". Emperor Akbar also endeavored to protect nature. Under Roman law, either no one or everyone owned these resources in common. The public trust doctrine casts a duty on the state to initiate the campaign for the protection of environment. During the regime of British's initiative were taken to save the planet earth and they enacted plethora of laws for the protection of environment. Post- Independence general provisions in Indian penal code and in the Constitution of India were incorporated for the said purpose. However, the legislators felt the need of specific and comprehensive legislation to preserve and protect environment. The need was also felt at International level, which is of recent origin for the protection of environment, and it was incorporated in UDHR and included as "Third Generation of Human Right." United Nations initiatives cannot be ignored in the form of principles of sustainable development, the principle of inter-generational equity, MDGs and SDGs. Despite all the initiatives, the degradation of environment is happening and planet earth is on the verge of destruction. The sovereignty over natural resources casts' duty on the state to take initiatives in furtherance of environment. The SC and $\mathrm{HC}$ enumerated under article 21 of the constitution that every citizen is having right to live in a healthy environment and everyone has right to clean drinking water. Human being since his inception has a right to live safe and healthy environment and water is inclusive of environment but human beings are the enemy of nature. Nature of modern technology, urbanization, per capita use of natural resources and developmental activities are some of the reasons responsible for the water crisis in India.

The need of the hour is to preserve our natural resources for present and the coming generations then only we will be able to meet the SDGs, which emphasizes on clean drinking water to be secured by 2030 . There are flaws in the implementation on the specific legislation on water preservation and the boards constituted are not discharging their duties. People do not take cognizance of this legislation rather they take recourse to Article 32 and 226 of the constitution.

The initiative to protect natural resources should be at an individual level. The development activities should go parallel with environment they should not happen at the cost of environment. Government has to take stringent steps for the protection of natural resources because human 
being is dependent on environment for every basic needs and life is beyond imagination without natural resource like WATER. The threat to sustainable management of water is an alarming situation and the way problem is progressing everyone in this universe is to be conscious to preserve this beautiful creation of god..... "THE PLANET EARTH".

\section{References}

About $60 \%$ of the States were marked as "low performers" and this was cause for "alarm," according to the report. Many of the States that performed badly on the index - Uttar Pradesh, Odisha, Chhattisgarh - accounted for $20-30 \%$ of India's agricultural output. "Given the combination of rapidly declining groundwater levels and limited policy action...this is likely to be a significant food security risk for the country," the report says.(See, The Hindu, June 14, 2018)

Bodenheimer, E. (2006): Jurisprudence 13 (5th rep., Universal law publications).

Divan, S. and Rosencranz, A. (2012): Environmental Law and Policy in India 167(14th ed., Oxford University Press).

Goel, P. K. (2014): Water Pollution: Causes, Effects and Controls, p. 8, 1st ed.

http://www.niti.gov.in/writereaddata/files/docum ent_publication/2018-05-18-Waterindex-Report_vS6B.pdf last visited on 31/07/2018.

http://www.undp.org/content/undp/en/home/sust ainable-development-goals.html last visited on 30/07/2018

https://www.businessstandard.com/article/current -affairs/40-of-indians-will-have-noaccess-to-drinking-water-by-2030-nitiaayog-118062500074_1.html last visited on $31 / 07 / 2018$.
Jaswal, P. S. and Jaswal, N. (2011): Environmental Law 16 (Rep., Allahabad Law Agency.

Krishnamurthy, K. V. (2007): An Advanced Textbook on Biodiversity, Principles and Practice, 142, 3rd ed. https://www.oecd.org/dac/environmentde velopment/FINAL\%20POST2015\%20gl obal\%20and\%20local\%20environmental $\% 20$ sustainability. pdf, visited on 2ndJune,2017.

Kummu, M.; Ward, P. J.; Hans, De M. and Olli, V. (2018): Is physical water scarcity a new phenomenon? Global assessment of water shortage over the last two millennia,

http://iopscience.iop.org/article/10.1088/ 1748-9326/5/3/034006/meta.

Matta, G. (2014): "A study on physico-chemical Characteristics to assess the pollution status of river Ganga in Uttarakhand." Journal of Chemical and Pharmaceutical Sciences, 7(3): 210-217.

Matta, G. and Kumar, A. (2015): Monitoring and Evaluation of River Ganga System in Himalayan Region with Reference to Limnological Aspects. World Applied Sciences Journal, 33 (2): 203-212.

Matta, G. and Kumar, A. (2017): Health Risk, Water Hygiene, Science and Communication. ESSENCE Int. J. Env. Conser. Rehab, 8(1): 179 - 186.

Matta, G. and Laura, G. (2016): Mercury, lead and arsenic: impact on environment and human health India. Journal of Chemical and Pharmaceutical Sciences, 9(2): 718 725 .

Matta, G.; Bhadauriya, G. and Singh, V. (2011): Biodiversity and Sustainable Development: A Review. ESSENCE - Int J for Env Rehab and Conser, 2(1): $72-$ 80. 
Matta, G.; Laura, G.; Kumar, A. and Machel, J. (2018): Hydrochemical characteristics and planktonic composition assessment of River Henwal in Himalayan Region of Uttarakhand using CPI, Simpson's and Shannon-Weaver Index. Journal of Chemical and Pharmaceutical Sciences, 11(1).

Mesfin, M. M. and Arjen, Y. H. (2018): Four billion people facing severe water scarcity,

http://advances.sciencemag.org/content/2 /2/e1500323.full.

Pranjape, N. V. (2015): Environmental Laws and Management in India, 1 (1st ed.,)

Public Nuisance can be defined as an unreasonable interference with a general right of the public. See, Chapter XIV of the Indian Penal Code containing sections 268 to 294-A deals with the offences affecting the public health, safety, convenience, decency and morals.

Quoted from the notes of IGNOU (2005): Sustainable Development: Issues and Challenges, 6-7,

Sahasranaman, P. B. (2012): Handbook of Environmental Law 1(2nd ed., Oxford University Press).

See Section 2(a) Environment Protection Act, 1986

See, Article 226, Indian Constitution.

See, Article 32, Indian Constitution.

See, Article 51A (g) Indian Constitution.

See, The Economic Times, June 26, 2018

See Article 21, Constitution of India

19812 SCR 516

See supra not 4 at 197.

(2009) 5 SCC 492 at 505.

(1992) 1SCC388

AIR 1996 SC 2715
(1998) 2 SC 530.

Air 1999SC812.

AIR2000SC3751.

(1996) 5 SCC 647.

Source, Water Resource Institute.

Thakur, K. (2007): Environmental Protection Law and Policy in India 1 (1st ed., Deep and Deep Publications).

The Government of India participated in the United Nations Conference on the Human Environment held in Stockholm June,1972 and strongly voiced the environmental concerns. To meet the objectives of the said conference the Environment Protection Act, 1986 was enacted under Article 253 of the Constitution.

The Stoic school of philosophy was founded by a thinker of Semitic origin by the name of Zeno (350-260 B.C.)

Tripathi, S. C. (2008): Environmental Law, 1 (3rd ed.)

Water" being a "state subject", the Parliament can exercise the power to legislate on "water" only under articles 249 and 252 of the Constitution. The Parliament enacted the Water (Prevention and Control of Pollution) Act, 1974 and it was first amended in 1988 to conform to the provisions of the Environment (Protection) Act, 1986 